\title{
PURIFICATION OF LANTHANUM OXIDE BY MAGNETIC NANO-COMPOSITE ALGINATE BEADS AFTER ITS CONCENTRATION FROM ACIDIC MONAZITE LEACH LIQUOR
}

\author{
Abd El-Fatah, A. I. L.* \\ * Nuclear Materials Authority, Cairo, Egypt.
}

\begin{abstract}
Lanthanum represents nearly fifth of Egyptian mineral monazite total rare earth content. Due to its great industrial importance in applications, the present research is directed to its concentration to the highest possible grade then, its purification from the other minor coherent neighbor rare earth elements (REEs). Rare earth hydrated oxide cake was produced from Egyptian crude monazite mineral (54\% purity, -125 mesh size) after its digestion with concentrated sulfuric acid, its dissolution with water, thorium separation, purification from uranium and then group precipitation of total rare earth elements as ammonium sulphates. Total REEs precipitate was transformed to its hydrated oxide form after its caustafication process. REEs hydrated oxide cake is subjected to process of cerium oxidation and separation. REEs cake after ceria separation contains nearly half of its content from lanthanum and subjected to air-ammonia precipitation scheme at different $\mathrm{pH}$ values to get a higher lanthanum concentrate, which reach to $78.6 \%$ purity with $85.5 \%$ recovery at pH5.8. Magnetic alginate beads are used as biosorbent for sorption of lanthanum (III) from an aqueous medium of $\mathrm{pH}$ 5.8. The magnetic alginate sorbent is one of the highest adsorption capacities, which equal $1.8 \mathrm{mmol} \mathrm{g}^{-1}$ or $0.25 \mathrm{~g} / \mathrm{g}$. Column of $57 \mathrm{~cm}$ length, $1.2 \mathrm{~cm}$ diameter with flow rate $1 \mathrm{ml} / \mathrm{min}$ experiment was carried out for adsorption of lanthanum which reaches to more than $99.68 \%$ purity with $80.7 \%$ recovery after elution with $1 \mathrm{~N} \mathrm{HCl}$ and $1 \mathrm{~N} \mathrm{CaCl}_{2}$ at $\mathrm{pH} 3.5-4$.
\end{abstract}

Keywords: Magnetic alginate; Monazite mineral.

\section{INTRODUCTION}

Monazite is a phosphate mineral with a rare earth content of approximately $70 \%$ rare earth oxide, primarily Ce, La, Pr and Nd (varies by deposit between $83.55 \%$ and $94.5 \%$ of total REO). It would consequently be considered a selective, cerium type mineral (Cesbron, 1986; Ferron et al., 1991; Gupta and Krishnamurthy, 1992, 2005; Trifonov, 1963). Monazite also includes 4-12 wt. \% thorium and a variable amount of uranium (values are typically small but have been reported to be as high as $14 \mathrm{wt}$. \%) (Gramaccioli and Segalstad, 1978; Gupta and Krishnamurthy, 2005).

Recently, lanthanides have the great demand for various functional materials (Kondo and Kamio, 2002). From the rare earth elements (REEs), lanthanum has special attention due to its technological importance because of increasing demands for advanced new materials. Current applications of lanthanum as a pure element or in association with other compounds are in super alloys, catalysts, and special ceramics and in organic synthesis (Palmieri et al., 2002). Many conventional methods for removing heavy metals, radionuclides and lanthanides from aqueous solution exist (Bhattacharyya and Sharma, 2004). These include adsorption, ion exchange, solvent extraction, coagulation, floatation, hyper-filtration, chemical precipitation, and reverse 
osmosis. All these conventional methods have some advantages as well as disadvantages, such as disposal of chemicals, resins and adsorbents to the nature may themselves be harmful.

Cost effective and sustainable production of high purity rare earth elements (REE) by solvent extraction and ion exchange techniques, but there are some problems of solvent extraction very complex, needs many steps to separate the REE ions in a high purity and causes a lot of environmental problems. In ion exchange process using resins as activated carbon (phosphorus modification and oxygen modification), Amberlite ${ }^{\circledR}$ and Lewatit ${ }^{\circledR}$ for the extraction of lanthanides as Nd, Ce, Er, La and Dy (Anja Grohme et al, 2014).

Synthesized resins have also been used in extraction of REEs. (M. Draye et al, 2000) described the alkaline polycondensation of 8-hydroxyquinoline with formaldehyde to obtain a polymeric resins. The selective uptake of $\mathrm{Eu}^{3+}$ from aqueous solutions containing $\mathrm{La}^{3+}$ was found to be due to the incorporation of 8-hydroxyquinoline in the molecular matrix of the phenolic resins.

Alginate, a natural high molecular-weight biopolymer composed of chains of 1 , 4linked $\beta$-D-mannuronic and $\alpha$-L-guluronic has attracted much attention because it is non-toxic, selective, efficient and inexpensive (Da Costa and Leite, 1991; Chen and Wang, 2001; Chong et al., 2000). It has been demonstrated that the alginates are capable of binding metal ions through carboxyl groups (Siegel and Siegel, 1973; Lim et al., 2008) and calcium alginate beads are usually prepared for their gel forming properties in the presence of multivalent cations (Martinsen et al., 1989).

Magnetic separation technique, using magnetic polymeric particles, is a quick and easy method for sensitive and reliable capture of inorganic or organic pollutants. The magnetic sorbents behave similar to or even better than various commercial adsorbents (Ngah et al., 2006). After the usage, the magnetic sorbent can be easily separated from the solution by simple magnetic force. In the literature, iron oxides have been found to be successfully used as composite materials with host materials in fabricating magnetic sorbent (Oliveira et al., 2003, 2004; Chang and Chen, 2006).

Lanthanum sorption using magnetic alginate was studied at different experimental conditions. The sorption is highly dependent on the solution $\mathrm{pH}$. Magnetic alginate sorbent is characterized by efficient sorption toward $\mathrm{La}(\mathrm{III})$ ions from aqueous medium at approximately $\mathrm{pH} 4$. The uptakes kinetic were described by the PSORE, while the distribution of the metal at equilibrium between the solid and the liquid is modeled by the Langmuir equation. The maximum capacity reached $1.8 \mathrm{mmol} \mathrm{g}^{-1}$ at $25^{\circ} \mathrm{C}$. The sorption process was found to be endothermic, spontaneous (especially at high relative temperature) and contributes to increase the randomness of the system. Magnetic alginate beads regeneration was performed using $0.1 \mathrm{M} \mathrm{CaCl}_{2}$ without loss of durability over six cycles. The regeneration efficiency was found to be in the range 89-93\% (Khalid Z. Elwakeela, et al, 2017).

In this paper, the extraction of lanthanum is performed by a functionalized magnetic solid. Solid phase extraction (SPE) is an attractive method that offers advantages of 
simplicity, flexibility, absence of emulsion, high enrichment factor, and is environmental friendly. The nature and the properties of the sorbent materials play an important role in the effective retention of analytes from the sample solution (Baghban N., et al, 2012).

\section{EXPERIMENTAL}

\subsection{Chemicals}

Sodium alginate with a molecular weight of 70,000-80,000 was purchased from Himedia (India). Fe(III) and Fe(II) salts, citric acid, calcium chloride, Hydrochloric acid, sulfuric acid, for solution preparations, double-distilled water was used. The $\mathrm{pH}$ of the solutions was adjusted to the required value with $0.01 \mathrm{~mol} / \mathrm{L} \mathrm{HCl}$ and $0.01 \mathrm{~mol} / \mathrm{L}$ $\mathrm{NaOH}$ solutions. All chemicals used with analytical grade.

\subsection{Analysis}

The most common analytical techniques used to determine lanthanum in monazite leach liquor and in the products produced by Ion Chromatograph (IC-UV-VIS) instrument (DX-500) manufactured by Dionex Corp., USA, ICP-OES (Prism ICP- high dispersion) (Teledyne leeman labs) and X-ray fluorescence (EDXRF) using Rigaku spectrometer NEX CG with polarized optics in EDXRF lab, pH meter (inoLab, pH Level 1, WTW, Germany), Nuclear Materials Authority, Cairo.

\subsection{Procedure}

\subsubsection{Synthesis of magnetic alginate}

Stoichiometric amount of Fe(III) and Fe(II) salts was dissolved in distilled water under vigorous stirring. Then, a solution of $\mathrm{NaOH}$ was added very slowly until the $\mathrm{pH}$ value was raised to $\sim 11$ at which a black suspension was formed. This suspension was then refluxed at $80^{\circ} \mathrm{C}$ for 4.0 hours under vigorous stirring and $\mathrm{N}_{2}$ gas.

Magnetic particles were separated from the aqueous solution by centrifugation, washed with double distilled water several times, and then dried in an oven over night. Coated particles were prepared by adding nano-magnetite to citric acid solution $(2.0 \% \mathrm{w} / \mathrm{v})$ and then the mixture was stirred for 30 minutes at $80^{\circ} \mathrm{C}$.

After precipitation, the coated particles were dispersed in water to obtain a stable ferrofluid. $50 \mathrm{~mL}$ of ferrofluid was added very slowly to mixing of $12 \mathrm{~g}$ of sodium alginate powder with double distilled water $\left(4.0 \% \mathrm{w} / \mathrm{v}\right.$ solution) at $50^{\circ} \mathrm{C}$. The mixture was further stirred for 3 hours to ensure the homogeneity of the system.

The obtained viscous solution was introduced dropwise using a syringe into $400 \mathrm{~mL}$ of $\mathrm{CaCl}_{2}$ bath $(5.0 \% \mathrm{w} / \mathrm{v})$. Regeneration of the magnetic alginate sorbent was carried out using $0.1 \mathrm{M} \mathrm{CaCl}_{2}$. Magnetic alginate beads have a good performance for repeated use up to at least six cycles. (Khalid Z. Elwakeela, et al, 2017). The structure of alginate was shown in figure 1 and figure 2 shows the structure after the reaction with $\mathrm{CaCl}_{2}$. (H. Abd El Monem, 2017). 


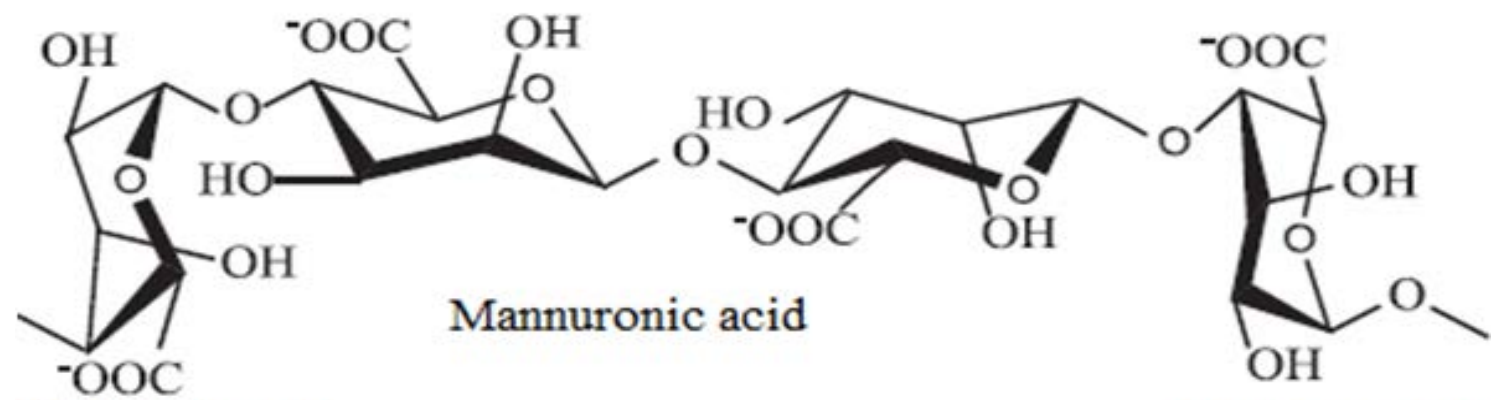

Guluronic acid

Guluronic acid

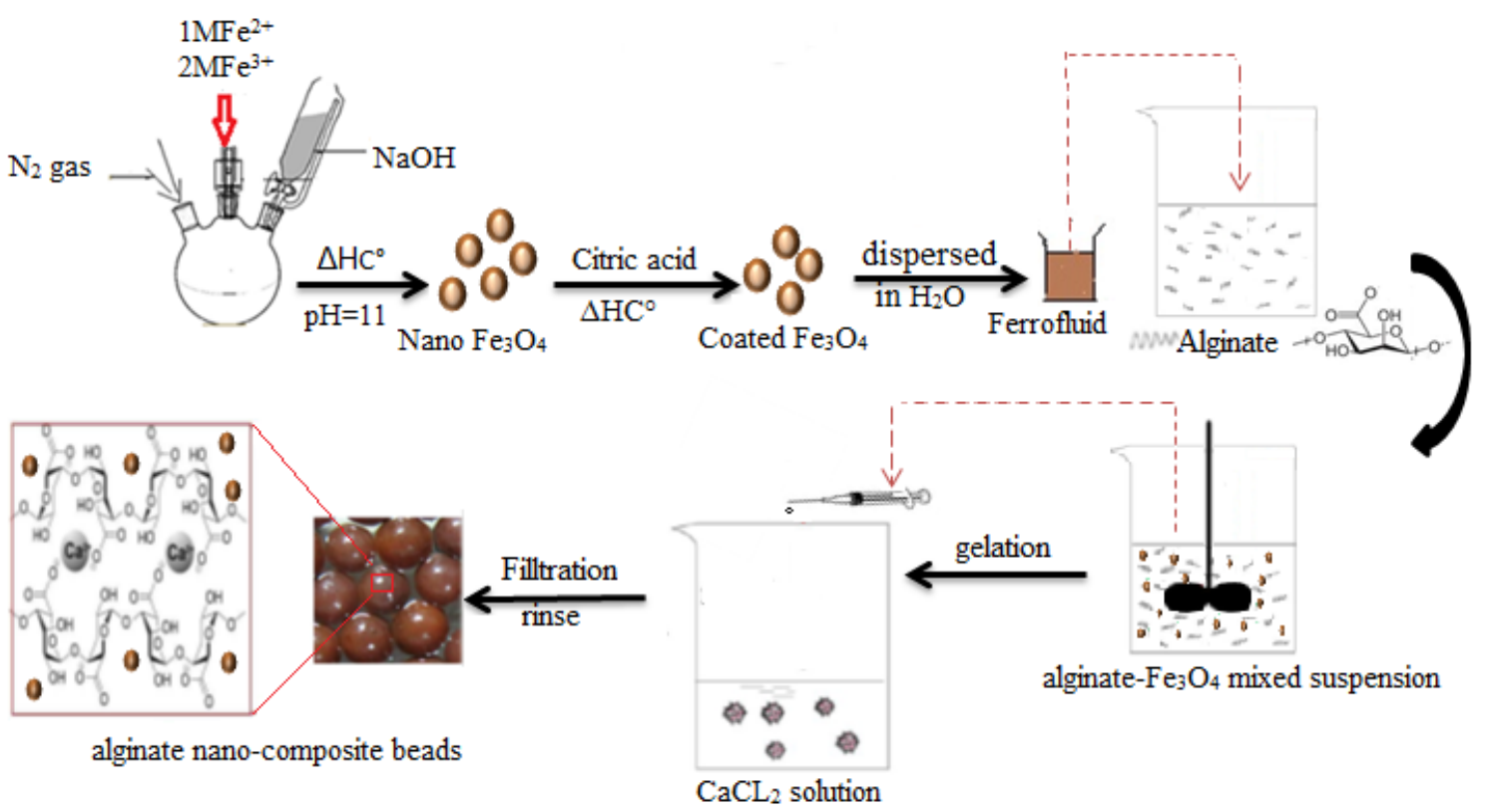

Fig. 1: Molecular structure of alginate macromolecules and the reaction of the formation of alginate nano-composite beads.
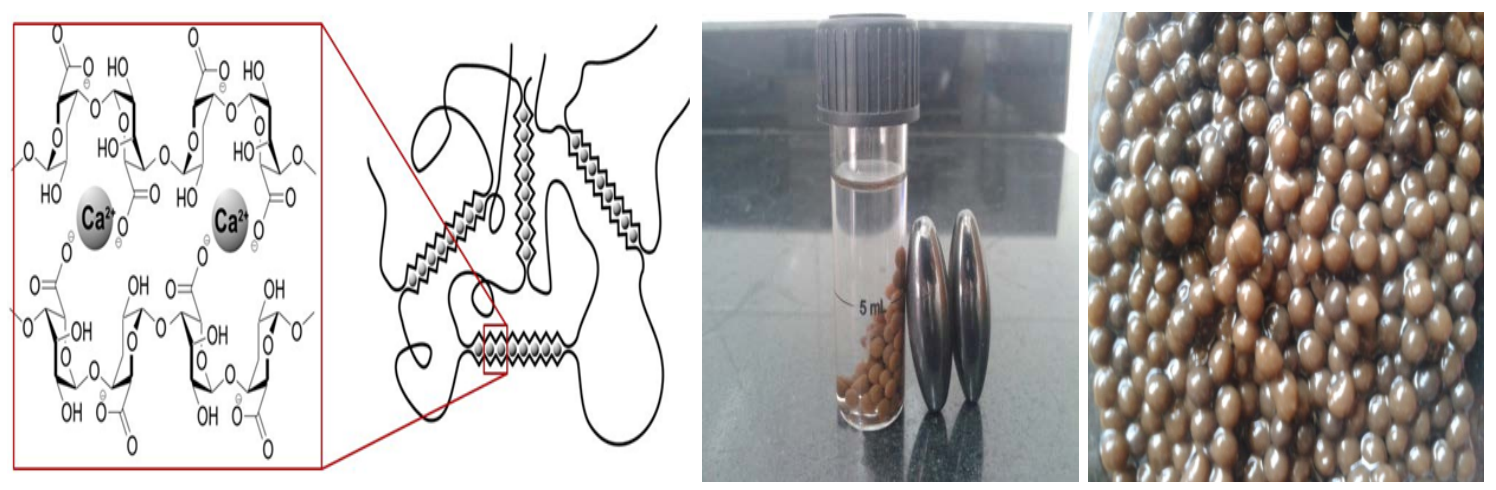

Fig. 2: Molecular structure of the prepared magnetic alginate. 


\subsubsection{Preparation of the acid leach liquor of monazite}

Monazite from black sands was used as raw material for the experiments. Monazite of $54 \%$ grade with -125 mesh size was digested with concentrated sulfuric acid with (1:2) ratio. Hence, $100 \mathrm{~g}$ of monazite mixed with concentrate sulfuric acid, stirring for $2.5 \mathrm{hrs}$ at $200-220^{\circ} \mathrm{C}$, and then diluted with iced water. The slurry was filtrated and the filtrate was diluted with water to $2 \mathrm{~L}$ (original solution), and the remaining residue constitutes silica, zircon and other undigested gangue minerals (Abd Elfatah, 2012).

Three main reactions occurring in the mineral digestion reaction as follows:

$$
\begin{array}{ll}
2 \mathrm{REPO}_{4}+3 \mathrm{H}_{2} \mathrm{SO}_{4} \longrightarrow & (\mathrm{RE})_{2}(\mathrm{SO} 4)_{3}+2 \mathrm{H}_{3} \mathrm{PO}_{4} \\
\mathrm{Th}_{3}\left(\mathrm{PO}_{4}\right)_{4}+6 \mathrm{H}_{2} \mathrm{SO}_{4} \longrightarrow & 3 \mathrm{Th}\left(\mathrm{SO}_{4}\right)_{2}+4 \mathrm{H}_{3} \mathrm{PO}_{4} \ldots \\
\mathrm{U}_{3}\left(\mathrm{PO}_{4}\right)_{4}+6 \mathrm{H}_{2} \mathrm{SO}_{4} \longrightarrow & 3 \mathrm{U}\left(\mathrm{SO}_{4}\right)_{2}+4 \mathrm{H}_{3} \mathrm{PO}_{4} \ldots
\end{array}
$$

\subsubsection{Thorium separation}

One litre from the original solution was taken to precipitate thorium at $\mathrm{pH} 1.3$ by ammonia solution (1:1), where thorium was precipitate as thorium pyrophosphate as the following equation:

$$
\mathrm{Th}\left(\mathrm{SO}_{4}\right)_{2}+2 \mathrm{H}_{3} \mathrm{PO}_{4} \longrightarrow \mathrm{ThP}_{2} \mathrm{O}_{7}+2 \mathrm{H}_{2} \mathrm{SO}_{4}+\mathrm{H}_{2} \mathrm{O}
$$

After thorium separation, the $\mathrm{pH}$ of the filtrate was adjusted by sodium hydroxide to 1.75 and filter again. The produced filtrate was then go to uranium decontamination step.

\subsubsection{Uranium decontamination}

The produced filtrate was passed through a column of Amberlite IR 402-Cl with flow rate $1 \mathrm{ml} / \mathrm{min}$ and bed height $16 \mathrm{~cm}$. The resin absorbs uranium from filtrate and passes the rare earth elements through the solution, which could be described by the following reaction (K. A. Rabie, 2016).

$$
\left[\mathrm{UO}_{2}\left(\mathrm{SO}_{4}\right)_{3}\left(\mathrm{H}_{2} \mathrm{O}\right)_{4}\right]^{-4}+(4+\mathrm{n}) \mathrm{HAmb} \longrightarrow\left[\mathrm{UO}_{2}\left(\mathrm{SO}_{4}\right)_{3}\left(\mathrm{H}_{2} \mathrm{O}\right)_{2}\right]^{-4}(\mathrm{HAmb}) \mathrm{n}+2\left[\mathrm{H}_{3} \mathrm{O}\right]^{+}
$$

\subsubsection{Hydrated oxide (hydroxide) preparation}

The produced solution from the column of resin (effluent) was precipitated by sodium hydroxide over stoichiometric ratio at $\mathrm{pH} 9$ then wash several times with water till neutralization.

$$
\mathrm{RE}_{2}\left(\mathrm{SO}_{4}\right)_{3}+6 \mathrm{NaOH} \longrightarrow 2 \mathrm{RE}(\mathrm{OH})_{3}+3 \mathrm{Na}_{2} \mathrm{SO}_{4}
$$

\subsubsection{Cerium separation}

Drying the produced hydrated oxides of rare earth elements at $110^{\circ} \mathrm{C}$ then oxidized at $160^{\circ} \mathrm{C}$ for 10 hours with airflow to oxidize cerium (III) to less basic cerium (IV). The cake was leached with $\mathrm{HCl}(1 \mathrm{~N})$ for 1 day, where the leaching is to dissolve the trivalent REEs leaving the less basic ceric oxide undissolved. 


\subsubsection{Lanthanum concentration}

After the removal of the unreacted part (solid ceric part), take the filtrate and a differential precipitation was performed first at $\mathrm{pH} 3$ and finally at $\mathrm{pH} 7$ by ammonia solution in the presence of air. The final filtrate was precipitated at $\mathrm{pH} 9$ by ammonium carbonate, which produces a concentrate of lanthanum precipitate.

\subsubsection{Reaction of lanthanum with magnetic alginate resin}

After precipitation at $\mathrm{pH} 5.8$ and before the final precipitation by carbonate, $700 \mathrm{ml}$ of the filtrate was withdrawn and passes through a column of the magnetic alginate beads with length of $57 \mathrm{~cm}$ and $1.2 \mathrm{~cm}$ diameter with flow rate of $1 \mathrm{ml} / \mathrm{min}$.

Cross-linked metal-alginate complexes are formed when the blocks of alginate macromolecular chains are mediated by trivalent metal ions. The exchange process takes place by the replacement of $\mathrm{Ca}^{+2}$ counter ions in the alginate macromolecule by trivalent metal ions from the external electrolyte solution. This exchange occurs inherently and stoichio-metrically as shown in equation 7.

$$
3(\mathrm{Ca}-\mathrm{Alg})_{\mathrm{n}(\mathrm{s})}+2 \mathrm{M}_{(\mathrm{aq})}^{+3}=\left(\mathrm{M}_{2}{ }^{\mathrm{III}}-\mathrm{Alg}_{3}\right)_{\mathrm{n}(\mathrm{s})}+3 \mathrm{Ca}^{++} \text {(aq) }
$$

\section{RESUltS AND DisCUSSION}

\subsection{Concentration of Lanthanum}

\subsubsection{Analysis of acidic monazite leach liquor}

The sulphuric acid process involves the digestion of monazite sands using hot concentrated sulphuric acid to form a monazite sulfate paste of rare earths and the remaining residue consists mainly zircon. The digestion reaction results a thick gray paste, so after cooling, it can be treated with about 20 parts of cold water to one part by weight of digested sand and leached for two hour, then filtration process. The produced acidic monazite leach liquor contains mainly 2.8\% $\mathrm{ThO}_{2}, 0.22 \% \mathrm{U}_{3} \mathrm{O}_{8}$ and $29 \%$ total $\mathrm{RE}_{2} \mathrm{O}_{3}$. The individual ppm of each element is illustrated in table 1.

Table (1): Chemical analysis of clear sulphates leach liquor of monazite.

\begin{tabular}{|c|c|}
\hline Rare earth elements & Concentration (ppm) \\
\hline $\mathrm{ThO}_{2}$ & 1400 \\
\hline $\mathrm{U}_{3} \mathrm{O}_{8}$ & 110 \\
\hline $\mathrm{La}_{2} \mathrm{O}_{3}$ & 3480 \\
\hline $\mathrm{Ce}_{2} \mathrm{O}_{3}$ & 6960 \\
\hline $\mathrm{Pr}_{2} \mathrm{O}_{3}$ & 870 \\
\hline $\mathrm{Nd}_{2} \mathrm{O}_{3}$ & 2030 \\
\hline Middle and heavy $\mathrm{RE}_{2} \mathrm{O}_{3}$ & 1015 \\
\hline
\end{tabular}

\subsubsection{Thorium separation}

From the experimental work, after monazite digestion, dissolution and filtration, the acidic leach liquor was firstly precipitated at $\mathrm{pH} 1.3$ to separate thorium as thorium pyrophosphate. The concentration of the acidic solution after complete thorium separation process was summarized in table 2. 
Table (2): The chemical analysis of monazite acidic solution after thorium separation.

\begin{tabular}{|c|c|c|}
\hline Rare earth elements & Concentration (ppm) & \% Recovery* \\
\hline $\mathrm{ThO}_{2}$ & Un-detected & ----- \\
\hline $\mathrm{U}_{3} \mathrm{O}_{8}$ & 107.5 & 97.73 \\
\hline $\mathrm{La}_{2} \mathrm{O}_{3}$ & 3470 & 99.70 \\
\hline $\mathrm{Ce}_{2} \mathrm{O}_{3}$ & 6530 & 93.82 \\
\hline $\mathrm{Pr}_{2} \mathrm{O}_{3}$ & 850 & 97.70 \\
\hline $\mathrm{Nd}_{2} \mathrm{O}_{3}$ & 2025 & 99.75 \\
\hline Middle and heavy $\mathrm{RE}_{2} \mathrm{O}_{3}$ & 990 & 97.54 \\
\hline
\end{tabular}

* \% recovery calculated related to the first acidic liquor elemental concentration in table 1.

\subsubsection{Uranium decontamination}

After thorium separation, the filtrate was secondly precipitated at $\mathrm{pH} 1.75$, which considers the suitable $\mathrm{pH}$ for passing through the resin; uranium was adsorbed at this $\mathrm{pH}$. The produced filtrate was passed on Amberlite IR402Cl column, which adsorb uranium ion, the produced raffinate contains most of rare earth concentrate.

Table (3): The chemical analysis of acidic solution after uranium separation.

\begin{tabular}{|c|c|c|}
\hline Rare earth elements & Concentration (ppm) & \% Recovery* \\
\hline $\mathrm{ThO}_{2}$ & Un-detected & ---- \\
\hline $\mathrm{U}_{3} \mathrm{O}_{8}$ & Un-detected & ---- \\
\hline $\mathrm{La}_{2} \mathrm{O}_{3}$ & 3465 & 99.57 \\
\hline $\mathrm{Ce}_{2} \mathrm{O}_{3}$ & 6505 & 93.46 \\
\hline $\mathrm{Pr}_{2} \mathrm{O}_{3}$ & 840 & 96.55 \\
\hline $\mathrm{Nd}_{2} \mathrm{O}_{3}$ & 2020 & 99.51 \\
\hline Middle and heavy $\mathrm{RE}_{2} \mathrm{O}_{3}$ & 980 & 96.55 \\
\hline
\end{tabular}

* \% Recovery calculated related to the first acidic liquor elemental concentration in table 1.

\subsubsection{Cerium separation}

The solution that passes from the column was caustaficated by sodium hydroxide, and then the produced precipitate was washed several times till neutral. The hydrated rare earth oxide was dried and oxidized in air with convection at $160^{\circ} \mathrm{C}$ for 10 hours to oxidize cerium III to less basic cerium IV, which was Leached by dilute hydrochloric acid $(1 \mathrm{~N})$ over night. The unreacted part contain $90 \%$ of less basic $\mathrm{Ce}_{2} \mathrm{O}_{3}$ and $10 \%$ $\mathrm{Ln}_{2} \mathrm{O}_{3}$, the analysis of cerium concentrate is demonstrated in table 4 . The product of cerium separation stage was declared in figure 3.

Table (4): The chemical analysis of cerium concentrate.

\begin{tabular}{|c|c|c|c|}
\hline Rare earth elements & Concentration (ppm) & \% Recovery* & \% Purity \\
\hline $\mathrm{La}_{2} \mathrm{O}_{3}$ & 346.5 & ------ & ------ \\
\hline $\mathrm{Ce}_{2} \mathrm{O}_{3}$ & 5854.5 & 84.12 & 88.91 \\
\hline $\mathrm{Pr}_{2} \mathrm{O}_{3}$ & 84 & ------ & ------ \\
\hline $\mathrm{Nd}_{2} \mathrm{O}_{3}$ & 202 & ----- & ------ \\
\hline Middle and heavy $\mathrm{RE}_{2} \mathrm{O}_{3}$ & 98 & ------ & ------ \\
\hline
\end{tabular}

* \% Recovery calculated related to the first acidic liquor elemental concentration in table 1. 


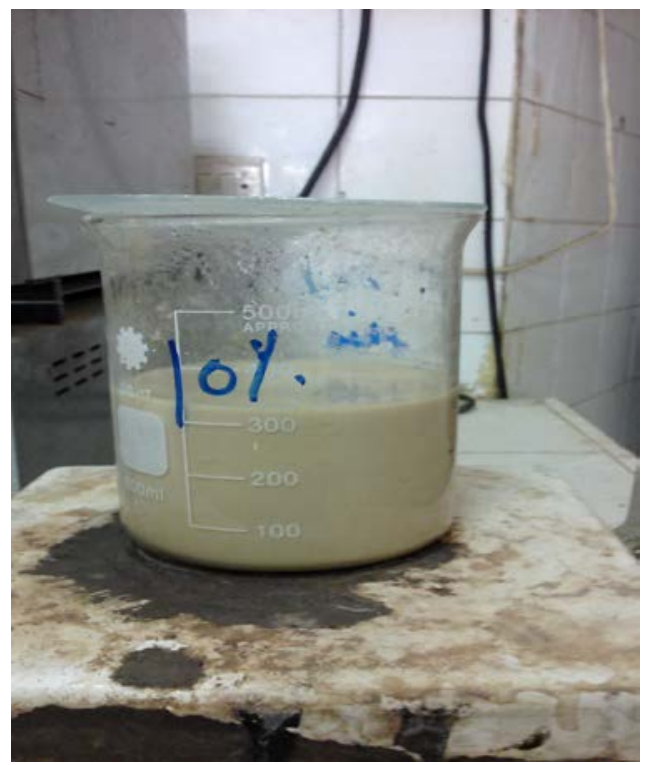

Fig. 3: Cerium separation process by leaching with 1N hydrochloric acid.

The analysis of the produced acidic leach liquor after filtration to remove the unreacted less basic ceric oxide was gathered in table 5.

Table (5): The chemical analysis of acidic solution after cerium separation.

\begin{tabular}{|c|c|c|c|}
\hline Rare earth elements & Concentration (ppm) & \% Recovery* & \% purity \\
\hline $\mathrm{La}_{2} \mathrm{O}_{3}$ & 3118.5 & 89.61 & 43.16 \\
\hline $\mathrm{Ce}_{2} \mathrm{O}_{3}$ & 650.5 & ------ & ------ \\
\hline $\mathrm{Pr}_{2} \mathrm{O}_{3}$ & 756 & 86.90 & ------ \\
\hline $\mathrm{Nd}_{2} \mathrm{O}_{3}$ & 1818 & 89.56 & ------ \\
\hline Middle and heavy $\mathrm{RE}_{2} \mathrm{O}_{3}$ & 882 & 86.90 & ------- \\
\hline
\end{tabular}

* \% Recovery calculated related to the first acidic liquor elemental concentration in table 1.

\subsubsection{Air-ammonia precipitation for heavier REEs than lanthanum}

After cerium separation, the acidic leach liquor was differentially precipitated at different $\mathrm{pH}$ values from 3 to 7 by air with ammonia solution. The analysis of each precipitate was illustrated in table 6.

Table (6): The chemical analysis of precipitates after applying air-ammonia precipitation scheme at different $\mathrm{pH}$ values.

\begin{tabular}{|c|c|c|c|c|c|}
\hline \multirow{2}{*}{ RH } & $\mathbf{3}$ & $\mathbf{4}$ & $\mathbf{5}$ & $\mathbf{6}$ & $\mathbf{7}$ \\
\cline { 2 - 7 } Rare earth elements & \multicolumn{5}{|c|}{ Concentration (ppm) } \\
\hline $\mathrm{La}_{2} \mathrm{O}_{3}$ & 31.19 & 62.37 & 124.74 & 249.48 & 1247.4 \\
\hline $\mathrm{Ce}_{2} \mathrm{O}_{3}$ & 325.25 & 455.35 & 520.40 & 585.45 & 617.98 \\
\hline $\mathrm{Pr}_{2} \mathrm{O}_{3}$ & 189 & 302.4 & 453.6 & 642.6 & 718.2 \\
\hline $\mathrm{Nd}_{2} \mathrm{O}_{3}$ & 545.4 & 727.2 & 1090.8 & 1545.3 & 1745.28 \\
\hline Middle and heavy $\mathrm{RE}_{2} \mathrm{O}_{3}$ & 352.8 & 441 & 661.5 & 793.8 & 864.36 \\
\hline
\end{tabular}


After precipitation at different $\mathrm{pHs}$, the precipitated values of each element were increased by $\mathrm{pHs}$ increase. The precipitation at $\mathrm{pH} 5.8$ was considered the most promising one because it precipitates most of the heavier rare earth elements than lanthanum with lesser lanthanum loss. The analysis of this precipitate is presented in table 7.

Table (7): The chemical analysis of precipitate at pH 5.8 after applying air-ammonia scheme.

\begin{tabular}{|c|c|c|}
\hline Rare earth elements & Concentration (ppm) & \% Recovery* \\
\hline $\mathrm{La}_{2} \mathrm{O}_{3}$ & 156 & ----- \\
\hline $\mathrm{Ce}_{2} \mathrm{O}_{3}$ & 580 & ------- \\
\hline $\mathrm{Pr}_{2} \mathrm{O}_{3}$ & 580 & 69.05 \\
\hline $\mathrm{Nd}_{2} \mathrm{O}_{3}$ & 1370 & 67.82 \\
\hline $\begin{array}{c}\text { Middle and heavy } \\
\mathrm{RE}_{2} \mathrm{O}_{3}\end{array}$ & 760 & 77.55 \\
\hline
\end{tabular}

The analysis of the produced leach liquor after filtration by air-ammonia method at $\mathrm{pH}$ 5.8 for lanthanum concentration was illustrated in table 8 . The product of air-ammonia precipitation process is shown in figure 4.

Table (8): The chemical analysis of the acidic liquor after applying air-ammonia precipitation scheme at pH 5.8.

\begin{tabular}{|c|c|c|c|}
\hline Rare earth oxides & Concentration (ppm) & \% Recovery* & \% purity \\
\hline $\mathrm{La}_{2} \mathrm{O}_{3}$ & 2962.5 & 85.5 & 78.56 \\
\hline $\mathrm{Ce}_{2} \mathrm{O}_{3}$ & 70.5 & ----- & ----- \\
\hline $\mathrm{Pr}_{2} \mathrm{O}_{3}$ & 176 & ------ & ----- \\
\hline $\mathrm{Nd}_{2} \mathrm{O}_{3}$ & 440 & ----- & ------ \\
\hline Middle and heavy $\mathrm{RE}_{2} \mathrm{O}_{3}$ & 122 & ------ & ------- \\
\hline
\end{tabular}

* \% Recovery calculated related to the first acidic liquor elemental concentration in table 1 .

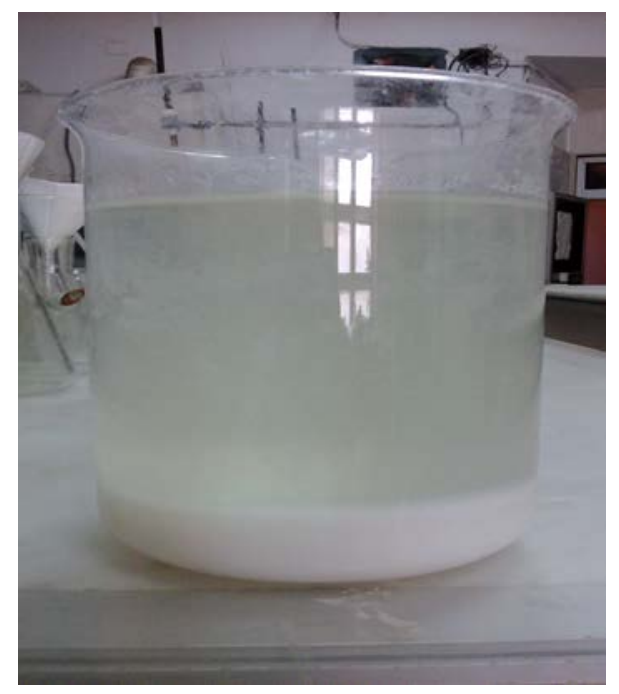

Fig. 4: Lanthanum separation (concentration) by air-ammonia method. 
After reaching these results, the steps were applied to the rare earth separation project, and the design of the applied unit for lanthanum separation was illustrated in figure 5. The prospected and applicable air- ammonia precipitation method was recommended to produce commercial lanthanum concentrate with higher purity and recovery at selected $\mathrm{pH}$ values which can be improved in a future lab works to be scaled up for industrial application.

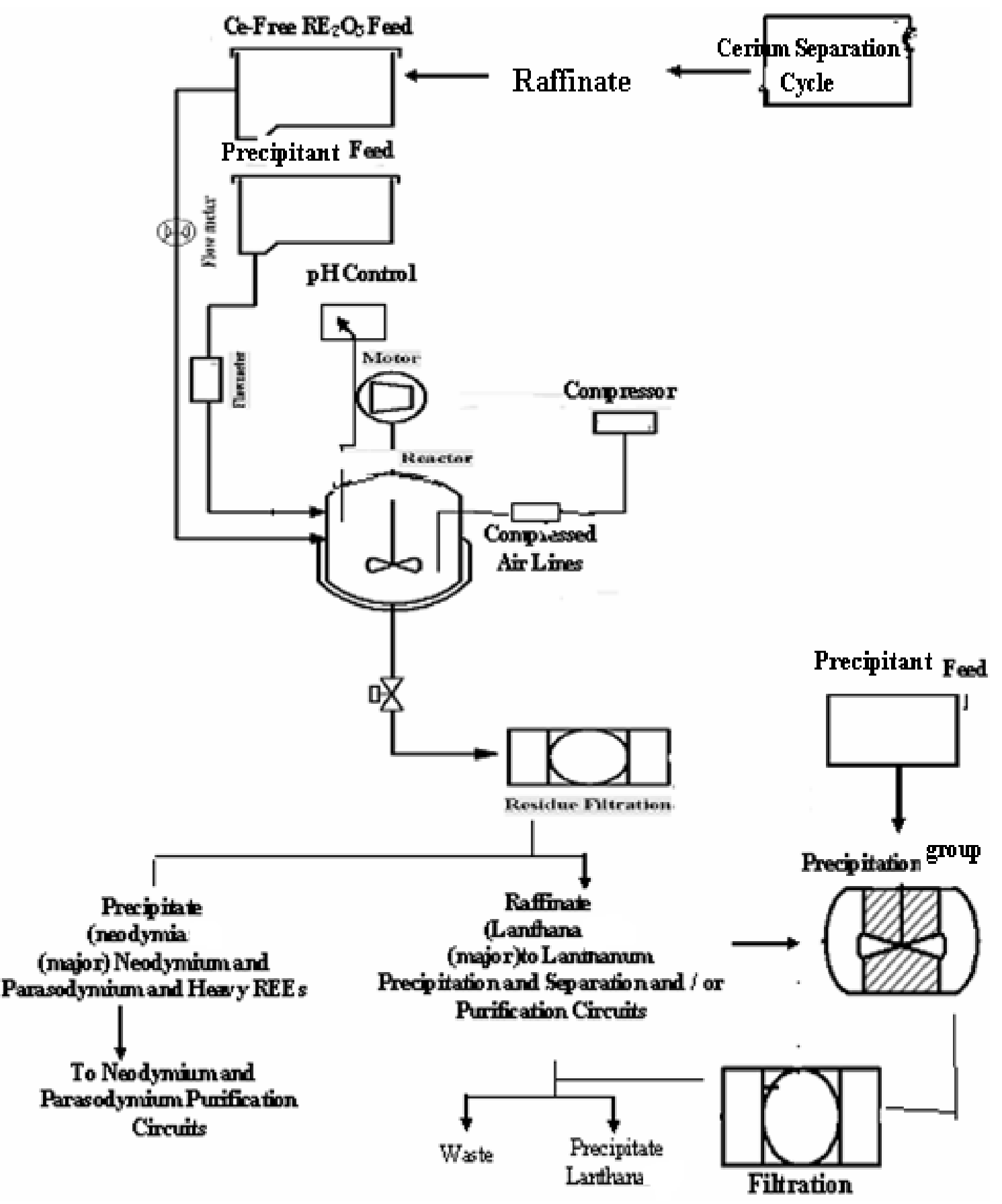

Fig. 5: Applied first design for the probable separation and concentration of commercial La. 


\subsection{Purification of Lanthanum by Using Magnetic Alginate Resin}

After precipitation at $\mathrm{pH} 5.8$, the resulted filtrate was passed through a column of magnetic alginate resin of $57 \mathrm{~cm}$ length, $1.2 \mathrm{~cm}$ diameter with flow rate of $1 \mathrm{ml} / 1 \mathrm{~min}$ (complete loading time was nearly 12 hours for $750 \mathrm{ml}$ loaded filtrate).

The analysis of the raffinate produced (totally collected) from column as shown in table 9. The elution was carried out by $750 \mathrm{ml}$ of $1 \mathrm{~N} \mathrm{HCl}+1 \mathrm{NCaCl}_{2}$ at $\mathrm{pH} 3.5-4$ in 12 stages (each cut was taken after 60 minutes) with the same rate of loading.

Table (9): The chemical analysis of the raffinate produced from the resin column.

\begin{tabular}{|c|c|c||}
\hline Rare earth elements & Concentration (ppm) & \% Recovery Inside the column \\
\hline $\mathrm{La}_{2} \mathrm{O}_{3}$ & Un-detected & 85.5 \\
\hline $\mathrm{Ce}_{2} \mathrm{O}_{3}$ & Un-detected & ----- \\
\hline $\mathrm{Pr}_{2} \mathrm{O}_{3}$ & Un-detected & ----- \\
\hline $\mathrm{Nd}_{2} \mathrm{O}_{3}$ & Un-detected & ----- \\
\hline Middle and heavy $\mathrm{RE}_{2} \mathrm{O}_{3}$ & 32 & ----- \\
\hline
\end{tabular}

Table (10): The analysis of the eluting solution of the $1^{\text {st }}$ five successive stages.

\begin{tabular}{|c|c|c|c|c|c||}
\hline \hline \multirow{2}{*}{ Eluting Stages } & $\mathbf{1}$ & $\mathbf{2}$ & $\mathbf{3}$ & $\mathbf{4}$ & $\mathbf{5}$ \\
\cline { 2 - 6 } Rare earth elements & \multicolumn{6}{|c||}{ Concentration (ppm) } \\
\hline $\mathrm{La}_{2} \mathrm{O}_{3}$ & 31 & 28 & 44 & 63 & 138 \\
\hline $\mathrm{Ce}_{2} \mathrm{O}_{3}$ & 25 & 15 & 16 & 10 & 4 \\
\hline $\mathrm{Pr}_{2} \mathrm{O}_{3}$ & 64 & 43 & 41 & 25 & 5 \\
\hline $\mathrm{Nd}_{2} \mathrm{O}_{3}$ & 85 & 164 & 179 & 8 & Un-detected \\
\hline Middle and heavy $\mathrm{RE}_{2} \mathrm{O}_{3}$ & 59 & 24 & 5 & Un-detected & Un-detected \\
\hline
\end{tabular}

After the elution of the fourth stage, we adjust the $\mathrm{pH}$ of the eluting solution to less than 3 by $\mathrm{HCl}$ to ensure the release of the rest of the element, after ensuring that the solution is free of most other elements.

All the eluting products were collected from step 5 through 12 for the production of pure lanthanum. The analysis of the collected eluting solutions was represented in table 11.

Table (11): The chemical analysis of the collected eluting solution from the 5 to 12 stage for pure lanthanum production.

\begin{tabular}{|c|c|c|c||}
\hline Rare earth elements & Concentration (ppm) & \% Recovery* & \% Purity \\
\hline $\mathrm{La}_{2} \mathrm{O}_{3}$ & 2806.5 & 80.65 & 99.68 \\
\hline $\mathrm{Ce}_{2} \mathrm{O}_{3}$ & 4 & ------- & ------- \\
\hline $\mathrm{Pr}_{2} \mathrm{O}_{3}$ & 5 & ------- & ------ \\
\hline $\mathrm{Nd}_{2} \mathrm{O}_{3}$ & Un-detected & ------- & ------- \\
\hline Middle and heavy $\mathrm{RE}_{2} \mathrm{O}_{3}$ & Un-detected & ------- & ------- \\
\hline
\end{tabular}




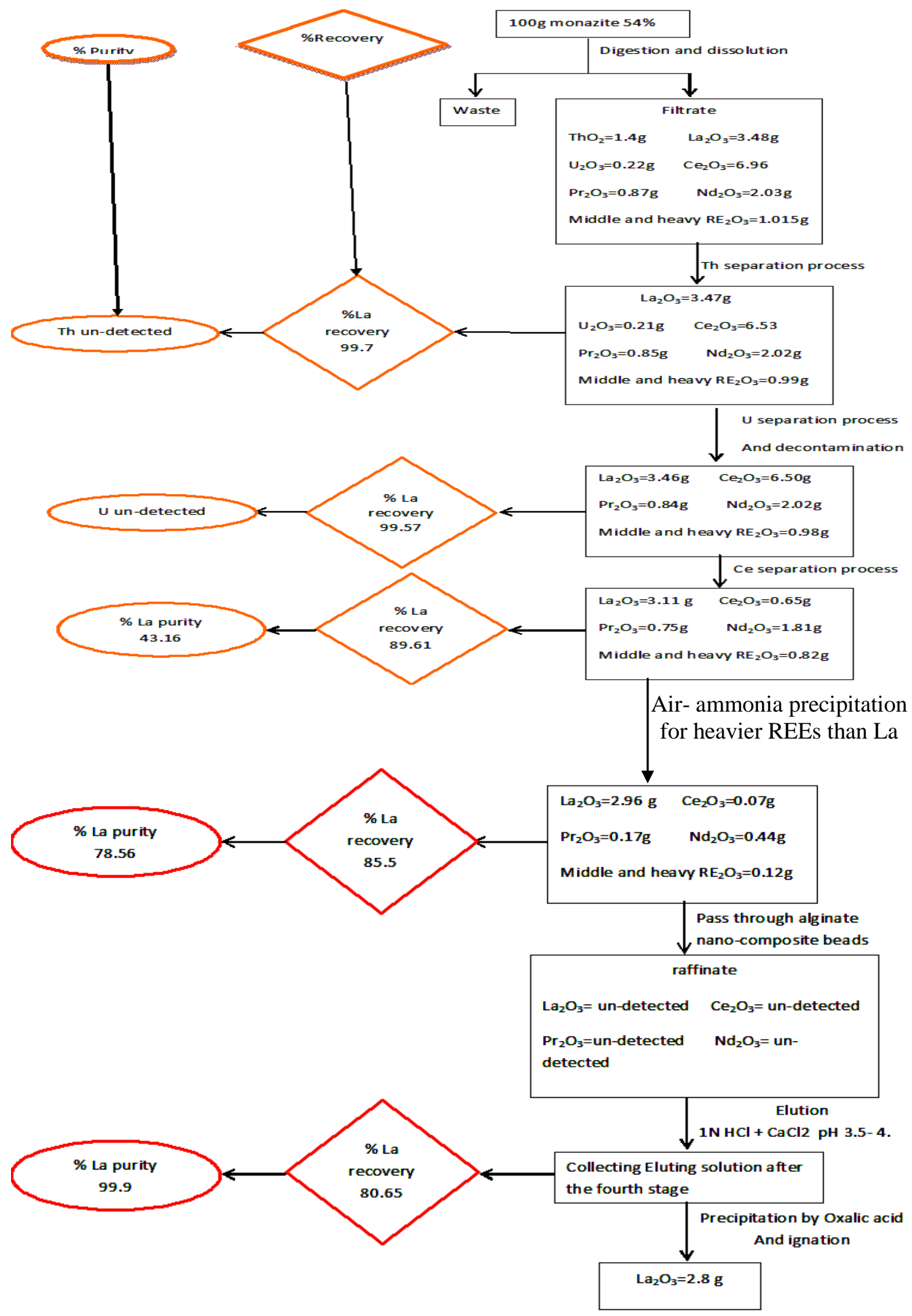

Fig. 6: Applied mass balanced flow diagram for separation \& purification of lanthanum. 


\section{CONCLUSION}

The Egyptian beach monazite mineral was digested in its impure native form ( $54 \%$ purity and -125 mesh size) by concentrated sulphuric acid. The produced paste was dissolute in cold water to sulphates acidic leach liquor of the mineral cations.

Thorium was first separated completely by precipitation at $\mathrm{pH} 1.3$ then rare earth elements consequently were precipitated at $\mathrm{pH} 1.75$ by dilute ammonia then transformed to sulphate form and treated by resin to be decontaminated from uranium. The produced raffinate was precipitated by soda and oxidized to remove cerium as Ce (IV) leaving trivalent rare earth elements. The trivalent clear solution was subjected to air-ammonia precipitation scheme for lanthanum concentration. By adjusting at $\mathrm{pH} 5.8$, most of trivalent rare earth elements were precipitated leaving lanthanum in the solution with $78.56 \%$ purity and the percent of recovery reaches 85.5 . Lanthanum concentrate solution was passed to a column of magnetic alginate beads of $57 \mathrm{~cm}$ length, $1.2 \mathrm{~cm}$ diameter with flow rate of $1 \mathrm{ml} / 1 \mathrm{~min}$. The elution was carried out by $750 \mathrm{ml}$ of $1 \mathrm{~N} \mathrm{HCl}$ $+\mathrm{CaCl} 2$ at $\mathrm{pH}$ 3.5-4 in 12 stages. Collect the eluting solutions from 5 to 12 stages for the production of lanthanum with more than $99.9 \%$ and $80.65 \%$ recovery.

\section{Acknowledgment}

The author thank Prof. Dr. Kamal Abdel Baky Rabie, Head of production sector, Nuclear Materials Authority, for suggesting the present topic of study and for continuous advice, supervision and valuable guidance during the progress of this work, without his efforts this work would not be possible. He has guided me through these years and his support, dedication and true concern for his students has enabled me to maximize my learning experience. For that, I am most grateful.

\section{REFERENCES}

[1] Abd Elfatah, A. I. L.: "Recovery of uranium during treatments of low-grade Egyptian monazite sand by sulfuric acid". Ph. D. thesis, faculty of science, Ain Shams university, Egypt, (2012).

[2] Grohme, A.; Tewes, E. and Peuker, U. A.: "Characterization of modified adsorption materials for selective separation on rare earth ions". International mineral processing congress IMPC 2014, Santiago, Chile | 20.10.2014, (2014).

[3] Baghban, N.; Shabani, M. and Dadfarnia, S.: "Solid phase extraction and determination of trace amounts of cadmium with cetyltrimethylammonium bromide-coated magnetic nanoparticles/ flame atomic absorption". J. Chin. Chem. Soc. 59(6):52, (2012).

[4] Bhattacharyya, K. G. and Sharma, A.: "Adsorption of $\mathrm{Pb}(\mathrm{II})$ from aqueous solution by Azadirachta indica (Neem) leaf powder". Journal of hazardous materials B113, pp. 97-109, (2004).

[5] Cesbron, F. P.: "Mineralogy of the rare-earth elements. In: Lanthanides, Tantalum (Ed.), and Niobium: Mineralogy, Geochemistry, Characteristics of Primary Ore Deposits, Prospecting, Processing and Applications". Society for geology applied to mineral deposits, Berlin, pp. 3-26, (1986).

[6] Chang, Y. C. and Chen, D. H.: "Recovery of gold (III) ions by a chitosan-coated magnetic nano-adsorbent". Gold Bull. 39, pp. 98-102, (2006). 
[7] Chen, J. P. and Wang, L.: "Characterization of a Ca-alginate based ion-exchange resin and its applications in lead, copper, and zinc removal". Sep. Sci. Technol. 36 (16), pp. 3617-3637, (2001).

[8] Chong, A. M. Y.; Wong, Y. and Tam, S. N. F. Y.: "Performance of different microalgal species in removing nickel and zinc from industrial wastewater". Chemosphere 41, pp. 251-257, (2000).

[9] Da Costa, A. C. A. and Leite, S. G. F.: "Metals biosorption by sodium alginate immobilized chlorella homosphaera cells". Biotechnol. Lett. 13, pp. 559-562, (1991).

[10] Ferron, C. J.; Bulatovic, S. M. and Salter, R. S.: "Beneficiation of rare earth oxide minerals. In: Conference, International. (Ed.), On Rare Earth Minerals and Minerals for Electronic Uses". Prince Sngkla University, Hat Yai, TH, pp. 251-269, (1991).

[11] Gramaccioli, C. M. and Segalstad, T. V.: "A uranium- and thorium-rich monazite from a south-alpine pegmatite at Piona, Italy". American mineralogist 63, pp. 757-761, (1978).

[12] Gupta, C. K. and Krishnamurthy, N.: "Extractive metallurgy of rare earths". International materials reviews 37 (5), pp. 197-248, (1992).

[13] Gupta, C. K. and Krishnamurthy, N.: "Extractive metallurgy of rare earths". CRC Press, Boca Raton, Florida, (2005).

[14] Abd El Monem, H.: "Extraction of lanthanides and iron from acidic matrix solution produced from monazite processing using chemically modified resins". Ph. D. thesis, faculty of science, Ain Shams university, Egypt, (2017).

[15] Rabie, K. A.; Abd El-Fatah, A.; Demerdash, M.; Salem, A. R.: "Empirical formulation for sorption kinetics of uranium on Amberlite-IRA-402 sorbent, Egypt". J. of Appl. Sci., 31 (2), pp. 60-77, (2016).

[16] Khalid, Z.; Elwakeela, B.; Daherc, A. M.; Abd El-Fatah, A. I. L.; Abd El Monem, H. and Mostafa, M. H. K.: "Biosorption of lanthanum from aqueous solutions using magnetic alginate beads". Journal of dispersion science and technology, 38: 1, DOI: 10.1080/01932691.2016.1146617, pp. 145-151, (2017).

[17] Kondo, K. and Kamio, E.: "Separation of rare earth metals with a polymeric microcapsule membrane". Desalination 144, pp. 249-254, (2002).

[18] Lim, S. F.; Zheng, Y. M. and Zou, S. W.: "Characterization of copper adsorption onto an alginate encapsulated magnetic sorbent by a combined FT-IR, XPS, and mathematical modeling study". Environ. Sci. Technol. 42, pp. 2551-2556, (2008).

[19] Draye, M.; Czerwinski, K. R.; Favre-RÉGuillon, A.; Foos, J.; Guy, A. and Lemaire, M.: Separ. Sci. Technol., 35, pp. 1117-1132, (2000).

[20] Martinsen, A.; Skjak-Brñk, G. and Smidsrd, O.: "Alginate as immobilization material: I. correlation between chemical and physical properties of alginate gel beads". Biotechnol. Bioeng. 33, pp. 79-89, (1989).

[21] Ngah, I. W.; Hwang, K. Y.; Jeon, C. and Choi, H. B.: "Removal of Pb ion from water by magnetically modified zeolite". Miner. Eng. 19, pp. 1452-1455, (2006).

[22] Oliveira, L. C. A.; Petkowicz, D.; Smaniotto, I. A. and Pergher, S. B. C.: "Magnetic zeolites: a new adsorbent for removal of metallic contaminants from water". Water Res. 38, pp. 3699-3704, (2004).

[23] Oliveira, L. C. A.; Rios, R. V. R.; Fabris, A.; Sapag, J. D.; Garg, K. V. and Lago, K. R. M.: "Clay-iron oxide magnetic composites for the adsorption of contaminants in water". Appl. Clay Sci. 22, pp. 169-177, (2003).

[24] Palmieri, M. C.; Volesky, B. and Garcia, O.: "Biosorption of lanthanum using Sargassum fluitans in batch system". Hydrometallurgy 67, pp. 31-36, (2002). 
[25] Siegel, B. Z. and Siegel, S. M.: "The chemical composition of algal cell walls". CRC Crit. Rev. Microbiol. 3 (1), pp. 1-26, (1973).

[26] Trifonov, D. N.: "The rare-earth elements". Macmillan, New York, (1963). 


\section{تنقية أكسيد اللانثانوم بواسطة خرز متراكبات النانو الجينات المغناطيسية بعد تركيزه من محلول المونازيت الحامضي مرئي}

\section{غزيزة إبراهيم لطفي عبد الفتاح \\ هيئة المواد النوويةــ القاهرة- مصر الهر}

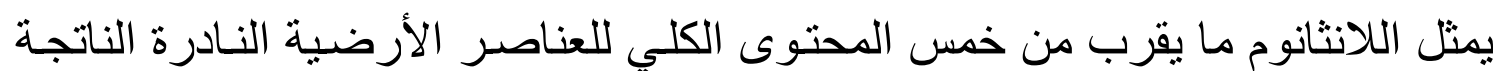

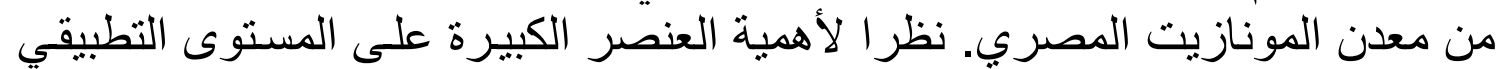

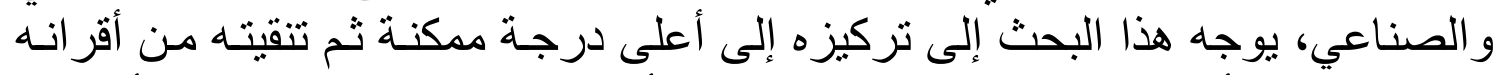

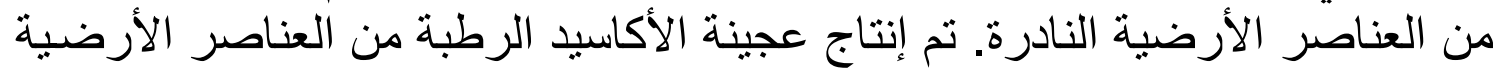

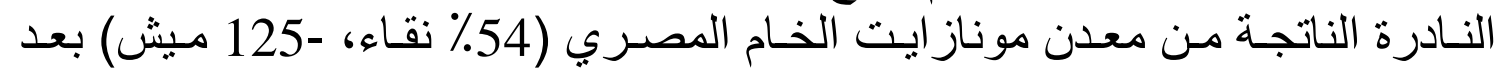

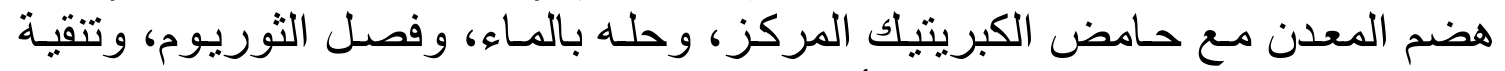

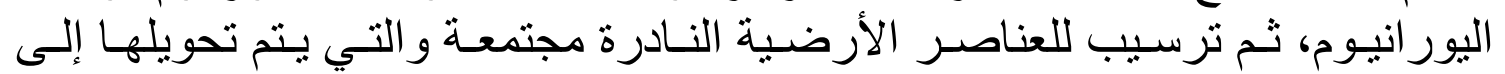

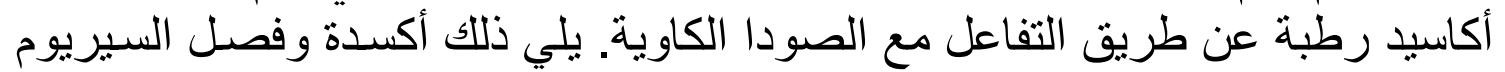

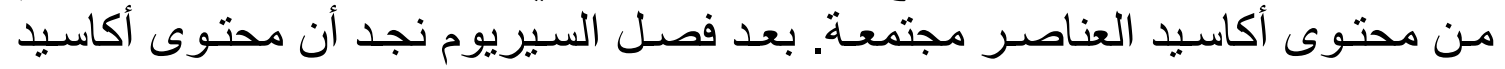

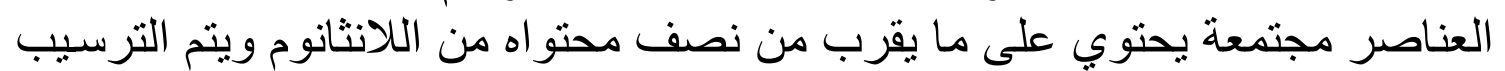

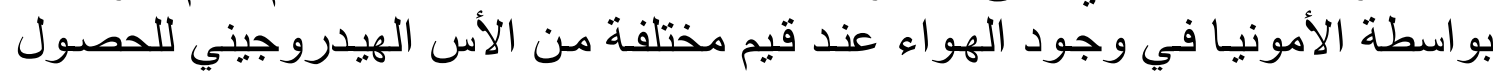

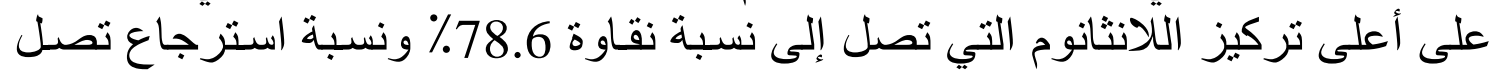

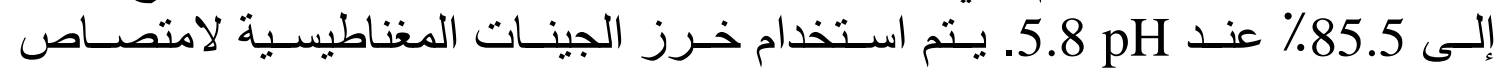

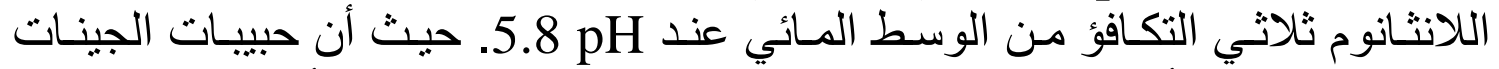

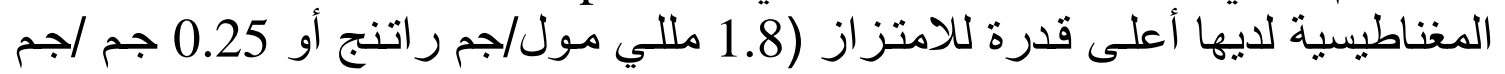

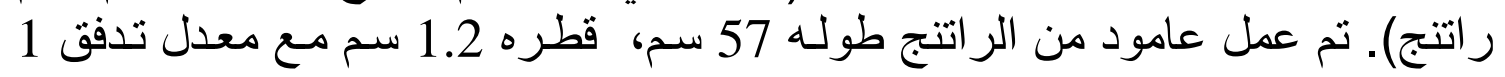

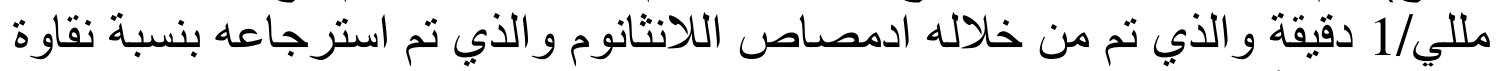

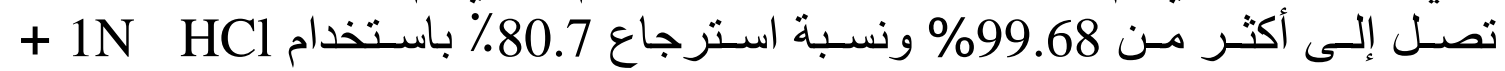
1 1 $1 \mathrm{NCaCl}_{2}$ 